\title{
CONTENTS OF CLINICAL HEMORHEOLOGY, VOLUME 10, NUMBER 2
}

\section{CONTENTS}

E. Ernst, T. Saradeth and G. Achhammer

D. Vorcliffe

T. DiPerri, F. Laghi Pasini, A. Acciavatti, D. Pieragalli, L. Domini, S. Pecchi, G.L. Messa, C. Frigerio, M. Materazzi, C. Galigani, M. Pastorelli, P. Blardi,

P. Damiani, F. Guideri, V. De Franco,

M. Saletti and A. Monaci

C. Tonelli, A. Catamo, E. Molina, A. Mombelloni, O. Ponari, S. Manfredo and S. Tardio

T.-H. Young, J. Cuttner, R. Meyer and S. Chien

Q. Ying, W. Baisheng, T. Ning, L. Guangze and $\mathrm{H}$. Youtian

M.-L. Bezençon, J. Roux, E.M. Grandjean and T. Imamura

J.L. Ambrus, J.M. Anain, S.M. Anain,

P.M. Anain, J.M. Anain, Jr., S. Stadler,

D. Fisher, M. Mahafzah, A. Hammad and J.P. Savitsky

J. Roux, M.-F. Maignan and F. Martinot

B.D. Smith, J.L. Thomas and J.A. Cillespie

E. Levi, O.K. Baskurt, S.S. Cağlayan,

K. Tahta, N. Dikmenoğlu and S.O. Andac
157 Blood cell rheology-Influence of exercise and omega-3 fatty acids

165 A laboratory evaluation of the HAAKE falling ball microviscometer

171 Haemodynamics, rheology and mechanism of action of Iloprost in man

185 Effects of i.v. glycerol on some hemorheological parameters in patients with acute stroke

191 Leukapheresis reduced blood viscosity in chronic myelogenous leukemia patients with hyperleukocytosis

205 Influence of hemorheological therapy on cardiac function after acute myocardial ischemia in rabbits

215 Denbufylline, pentoxifylline and Zy 16075 decrease rat arterial and venous blood viscosity, but not human venous blood viscosity in vitro

225 The effects of pentoxifylline (Trental) on circulating platelet aggregates and platelet aggregation patterns in patients with chronic obstructive arteriosclerotic disease

231 In vitro effect of $\mathrm{O}-(\beta$-Hydroxyethyl)-rutosides* on rat erythrocyte morphology

241 Abnormal erythrocyte endothelial adherence in ischemic heart disease

Brief Communication

255 Erythrocyte deformability does not change due to experimental hypothyroidism

259 Announcement

261 Contents of BIORHEOLOGY, Volume 26, Number 6

I Software Survey Section 